\title{
Support network and social support for children with special health care need
}

\author{
Rede de apoio e apoio social às crianças com necessidades especiais de saúde
}

Thaís Araújo Barbosa ${ }^{1}$, Kamilla Milione Nogueira Reis ${ }^{1}$, Gabriela de Oliveira Lomba ${ }^{1}$, Gabriela Vilaça Alves ${ }^{1}$, Patrícia Pinto Braga ${ }^{2}$

Objective: to understand and identify the support network and social support from the perspective of families of children with chronic conditions. Methods: a qualitative study, with content analysis of 134 records, followed by ten semi-structured interviews. Results: the analysis has revealed that the primary caregiver, the mother, participates in a network of limited support, only with the help of her husband, children, grandparents and the child's godparents. They also have a social network through a multidisciplinary team, which in some cases is not effective. Conclusion: families have a deficient and limited support network and the demand for care rely only on the support of the husband, grandparents, children, and godparents. Social networking refers to the philanthropic institutions, while the aid of public service, basic health unit is basic.

Descriptors: Social Support; Caregivers; Child; Chronic Disease.

Objetivo: compreender e identificar a rede de apoio e social sob a ótica das famílias de crianças com condições crônicas. Métodos: estudo qualitativo, com análise de conteúdo de 134 prontuários, seguido por 10 entrevistas semiestruturadas. Resultados: a análise permitiu revelar que o cuidador principal, a mãe, participa de uma rede de apoio restrita, somente com a ajuda do marido, filhos, avós e padrinhos da criança. Também contam com uma rede social, através de uma equipe multiprofissional, que em alguns casos não é resolutiva. Conclusão: as famílias possuem rede de apoio deficiente e restrita e para a demanda de cuidados contam apenas com o apoio do marido, avós, filhos e padrinhos. A rede social refere-se às instituições filantrópicas, enquanto é incipiente o auxílio de serviço público, de Unidade Básica de Saúde.

Descritores: Apoio Social; Cuidadores; Criança; Doença Crônica.

\footnotetext{
${ }^{1}$ Universidade Federal de São João Del Rei. Divinópolis, MG, Brazil.

${ }^{2}$ Universidade Federal de Minas Gerais. Belo Horizonte, MG, Brazil. 


\section{Introduction}

In recent years, with technological advances and implementation of strategies and health actions aimed at reducing infant mortality, a reduction in the mortality rate of this group from infectious and immune-preventable diseases. However, there is an increased incidence of illness and death identified from perinatal conditions ${ }^{(1)}$.

Children survivors of these technological advances have chronic health conditions, sequels and get some special need during life. A chronic condition during childhood interferes with the functioning of the body of the child, requiring assistance and follow up with health professionals, limiting daily activities and causing repercussions on their growth and development process, affecting the daily life of all family members ${ }^{(2)}$.

Faced with the conceptual diversity and complexity in the lives of these children, the Maternal and Health Children Bureau in the United States defines this group of children as Children with Special Health Care Needs ${ }^{(3)}$. In Brazil, they were called for Children with Special Health Needs, being also known as heirs of technology ${ }^{(4)}$.

In Brazil, children with special health care needs were classified into five groups according to the type of care required. In the first group, there are the kids with neuromuscular dysfunction requiring psychomotor and social rehabilitation. In the second group, those technology dependents. In the third group, there are the drug addicts. In the fourth group, those dependents on modifications in the usual way to take care, including performing common tasks of everyday life. In the last group, those having two or more of these demands together ${ }^{(5-6)}$.

Given this clinical complexity, children with special health needs are subject to prolonged hospitalization and frequent readmissions, requiring complex care for a better quality of life, being considered that way, as medically fragile and socially vulnerable $e^{(4)}$. Because of the particularities of care required, they are part of a group that represents a challenge for families and caregivers ${ }^{(7)}$.

Considering the above, we recognize that the chronic condition in childhood is an important theme for reflection of the adaptation process and family coping with the limitations that this condition imposes on the family system.

In this study, the definition of family was adopted: the family is whom its members say they are ${ }^{(8)}$. Thus, the research considered as family, people linked by blood and by civil union, apart from those bound by emotional consideration or define themselves as part of it.

In this sense, families and children with special health needs require a social network and wellestablished support. The social network refers to structural or institutional dimension connected to an individual. It is a web of relationships linking the various individuals who have social ties, providing the support resources flow through these links, churches and health institutions ${ }^{(9)}$. The support network is a process of interaction between people or groups of people, who through regular contact establish bonds of friendship and information, receiving material, emotional, emotional support, contributing to the reciprocal well-being and constructing positive factors in prevention and health maintenance ${ }^{(9)}$.

Therefore, the demand for care provided by that child group requires the involvement of a support network and social network, composed of health services, family, and community, able to assist primary care providers in making decisions, turning them into autonomous subjects and aware of their attitudes. Thus, this research aims to understand and identify the network of support and social network in which families are inserted. 


\section{Methods}

It is a qualitative study. This research mode allows having a subjective and particular understanding of the subject, based on a real experience, experienced in everyday life, providing details of local contexts and moments in the certain time ${ }^{(10)}$.

The research was held from November 2013 to July 2014. For its development, there were two stages complemented. The first phase was to perform the mapping of all children attending a philanthropic institution in a municipality in the Mid West of Minas Gerais. There were 134 children to identify their profile (gender, age, morbidity, complications in the period perinatal, types of limitations of children with special health needs, socioeconomic status, etc.) and select the ones that would meet the inclusion criteria for the realization of the second stage of the study.

Inclusion criteria for the second stage were dependent children in activities of daily living than expected for their age (hygiene, nutrition, mobility); being part of the fifth type classification group of care required (two or more types of dependencies ${ }^{(5-6)}$; and assisted by family members who have a direct care to them, over 18 years old and full civil capacity. No exclusion criteria were used.

There were 37 children identified with special health care needs who met the criteria. With this sample, the researchers contacted the families for the invitation to participate and scheduling interviews. Ten interviews were conducted, when there was saturation of information from different households.

The interview was by guiding questions related to the care of routine, found facilities and challenges, discovering the particular needs of health, type of support received and from whom, type of benefits, health services used, which institutions support and multidisciplinary team care. Such issues have been introduced during the development of the interview, and the skilled researcher to insert the questions during the interaction, so getting great testimonials for analysis.

The qualitative data analysis took place according to the following aspects: pre-analysis, exploration of material and treatment of results consisting of inference and interpretation ${ }^{(11)}$. Thus, the interviews were transcribed and then coded to ensure the anonymity of the participants. A brief reading and then a thorough reading of the statements was carried out to capture the main ideas presented by the caregivers of children about the support network for social support present in their daily lives. After reading, the speeches were grouped into categories and subcategories and through them, data interpretation was performed with a grounding in the theoretical framework, allowing the construction of an analytical text.

The study complied with the formal requirements contained in the national and international regulatory standards for research involving human beings.

\section{Results}

Thematic categories and subcategories were created, which enabled and facilitate the analysis of the speeches, which were: Caregiver Profile, Family Structure, Home care, Types of support, Health services, Multi-professional team, Child stimulation with special health care needs, Financial situation, Home adaptation of physical structure, Transportation, Spirituality, Leisure, School inclusion and Pregnancy.

Study participants in the second stage of the research were families of children with special health care needs who had several limitations in daily life, dependent in activities of daily living and need of a special rehabilitation therapy. During the life of the child, the family faces with difficulties in the search for diagnosis and weaknesses in professional assistance. Thus, it is necessary to travel to other cities in search of effective and quality care, as can be seen in the following reports: He started to cry, and it was like he was killing 
for about 15 days. Every day in the hospital, the doctor would see: it is colic, is an earache, and it was nothing. From time to time the little head fell, and he rose his little eye, the nurse would say, it is nothing, he is in pain (E7). I was in the hospital, I remember they called three orthopedic surgeons to be able to see him, they were very experienced orthopedic surgeons, and none wanted to look or put their hands, just he said it was the case for Belo Horizonte, which was not the case here, they did not know what it was (E3).

Another difficulty found by families refers to network deficient and restricted support. The mother, who in most cases is the main caregiver, takes much of the demand for care to the best quality of special needs with children's lives and health has been identified that they can rely only on her husband's support, grandparents, children, and godparents. Thus, despite this support received, there is an overload in the life of the main caregiver, which causes considerable physical and emotional exhaustion. This is evidenced by the following statements: Who helps me is only his father. There are some people like the godmother, my mother, who sometimes helps, stay with him a little bit if I need to leave, something like that, but otherwise, just ourselves: me, him and his father (E1). The support I have is my husband who supports me a lot... However, he helps me a lot in taking him, look for him, do sleep. By the time, I'm tired he take cares of him (E2).

In the following speeches, it is realized that the families of the children feel the need to exchange experiences with other families who also undergo similar situations. Thus, only one family revealed to have had the opportunity to receive support from another family. I have no guidance; I do everything by myself. I think there should be a group of specialist for children's parents in the West syndrome, each one has an experience, those just starting out can learn from me, I will learn from the older because I think everyone is always willing to learn, always wanting to know what caused it, what happens, as I'll take care, what he can eat (E7). I found a case here ... I went to her mother, she came and helped me, guided, spoke as was explained to me how he was treating, that helped me also (E3).

In addition to the support network, families reveal that they receive help from philanthropic institutions, which is necessary for a child's best quality of life. Only one of the families reported receiving assistance from a Basic Health Unit. This can reveal a weakness in primary care about the targeted assistance to children with special health care needs. The support network evidenced by the subjects can be seen in the following statements. The staff of the institution supports the family with almost everything; we are always asking opinion to them (E2). When I have doubts, I'm going to the health center near my house and ask (E5).

Families also need guidance and involvement of a multidisciplinary team, so that they feel safe and have skill in performing the procedures at home. Through the speeches, it is possible to see that families receive support from a multidisciplinary team that guides and allows the child to get quality care. However, a family says there is a weakness in the guidance received. The team is an occupational therapist, a speech therapist, a motor therapist, respiratory therapist, educator, nurse, dentist, neurologist and pediatrician (E2). The care that the medical reports are reinforced by professionals! The work that the therapist guides, the exercises to do with him, physiotherapy exercises, we feel well-oriented, yes (E1). I was not guided, I'm asking a lot, I go to the doctor and ask, and if it happens? Moreover, if there is a crisis? (E7).

The analysis of speeches identified that despite the difficulties encountered in home care, families recognize the importance of health professionals, which are essential in the development of children with special health care needs. The attention that I need from them, I feel they do not give me, doubts that we have we ask, it is all cleared up ... it is good a care of them, I have nothing to complain about (E1). They are very dedicated to my son ... they have much love ... Much professionalism, and it is excellent (E2).

There are difficulties encountered by families with the Unified Health System, as the psychological services are time-consuming and bureaucratic. However, families recognize the importance of the Unified Health System and the benefits it provides to the child and family, evidenced in the following statements: What the Unified Health System offers we cannot complain, it is not bad ... However, because sometimes it is very timeconsuming. (E1). I wish it were easier to everything you need, you cannot get an appointment. For an assistance of the speech therapist, it takes six months. Then, suddenly the boy is severe, God forbid me, 
in the case of special child, you lose (E7). The health center is not good ... sometimes they go, ask about weight, over the measure. Then, it is schedule the assistance to go to the service, I take him, but professionals are not always at the scheduled day ... (E5). Sometimes I needed I was treated well, my son was treated well ... we did the surgeries. We did them by the Unified Health System, the time that I was there at the hospital I did not have financial expenses because the hospital gave me all, then, that to me was very good because imagine a person without resources, stay there without eating or drinking. And the hospital supported all this, then, it has its good side too (E5).

To meet the needs for assistance to that child group, the family uses private services and health plans. It was revealed that one of the families cannot afford to purchase a health insurance, so they only use the services offered by the Unified Health System. Another family reports do not realize the difference between private and public services. I decided to do the health insurance to meet the possible emergency because the plan is sure that I will have to promptly need help (E1). I've already paid consultation. You can see the difference when you're in the money and when you do not have it (E5). So far, I could not pay for treatment, but now I'll see if I can. If I had insurance I would had already taken him to an orthopedist (E8). I always thought about doing a health insurance, but what turns me off is because it ends up, all the same (E5).

\section{Discussion}

The discovery by the parents of a chronic condition during the childhood is a situation that causes profound changes in routine ${ }^{(12)}$. In addition to causing changes in intra-family relationships, they are strongly shaken and permeated with various behaviors, such as negative feelings, take care of a disability person, frailty, guilt, insecurity, worry, fear, and anxiety.

The family goes through periods of adjustment, because of the special care demand that these children need and having an intense disorganization in their routine, permeated with suffering and anguish generated by the limited contact with the child ${ }^{(13)}$. Also, this study, like others, has identified a backlog of tasks on the main caregivers, reducing the family's privacy and causing social and emotional isolation ${ }^{(14)}$.

Usually, the mother is the main involved in home care to this child group, taking all care demands and tasks required by the child ${ }^{(15-16)}$. This is explained by the fact that care is culturally a task delegated to women. However, the survey identified that others help in the routine care, such as grandparents, especially maternal and child's parents, when not in working hours, they provide supportive care ${ }^{(16)}$. Thus, it is clear the burden of care for only one family member, which ends up causing considerable physical and emotional distress to that primary caregiver.

Therefore, with this clear overload, especially maternal, there is a small support network, where the main caregiver counts only on her husband's help, the child's grandparents, godparents and children most of the time. It can still see that there is a weakness in the social network, where most of the families has a small number of institutions that could assist these children.

Another type of support that could be identified as positive for one of the families was to exchange experience with other families of children with special health care needs. This fact allows the passage of knowledge and clarification of doubts among family members. Thus, the support of other families of children with special needs proved to be an incentive to another household in overcoming the problems experienced in the home care routine.

The support of a multidisciplinary team is also needed to monitor and guide caregivers in understanding the therapeutic process and in addressing the child's diagnosis ${ }^{(16)}$. Thus, discourse analysis allowed revealing that there is a multiprofessional working with children with special health care needs and their families.

Thus, the assistance provided to this child group requires that the health professionals be inserted in the housing context so that they can understand the dynamics of the family in the care process, providing a humanized and quality care to meet the particular needs of each family core requirements ${ }^{(7)}$. 
It is essential that the health staff guide the family members in the practice of care, using a clear and efficient communication and being involved in the planning of such assistance so that caregivers feel safe and have skill in carrying out procedures ${ }^{(17-18)}$.

Therefore, it should be thought about the importance of building an effective social network for these families with a health team prepared to meet the demands of care of children with any special needs. Thus, that primary care services can view the home environment as an extension in care practice.

Currently, the Brazilian scenario shows the absence of specific public policies for that child group, which contributes to the fragility assistance to these children, different to the guidelines of the Unified Health System and its fundamental principles ${ }^{(18)}$. In this sense, due to this program vulnerability, with gaps and failures in public policy and health services, families seek help in the judiciary, so that children with special health care needs can have access to assistance and equipment necessary to continue the treatment. The legal protection and the creation of specific public policies aimed at this audience are crucial for families to be supported and these kids have quality care ${ }^{(18)}$. Currently, we experience a process of legalization assistance to these children in an attempt to foster minimum conditions for survival.

\section{Conclusion}

The survey revealed that there is a burden on a family member, most often the mother, in the care of children with special health care needs. The support network of survey participants proved to be fragile which is worrying when we refer to children with special health care needs who have needed care complexities in their daily lives. Also, we identify a stable and well-established social network is required so that caregivers can acquire knowledge and achieve an adaptation to the child experienced health situation.

This study revealed that the multidisciplinary team is necessary in care to children with special health care needs that present various demands related to rehabilitation and reduction of complications arising from their chronic conditions. The inclusion of the family in the decisions of treatment plans proposed by this public can foster learning and adaptation of families in managing the children with special health care needs. The multidisciplinary team will promote and encourage the family to identify a network of social support and for the care required by children with special health care needs.

The lack of practices and activities aimed at children with special health care needs and their families in primary health care services showed the need for training professionals to meet this growing audience.

It is necessary to expand health practices and encourage public policies to these children, to benefit children and their families.

\section{Collaborations}

Barbosa TA, Reis KMN, Lomba GO and Alves $\mathrm{GV}$ contributed to the conception and design, analysis and interpretation of data, article writing and critical review and final approval of the version to be published. Braga PP contributed in guiding the research, relevant critical review of the intellectual content and final approval of the version to be published.

\section{References}

1. Silva SMM, Mattos LCG, Macedo LF, Araújo TS. Morbidade e mortalidade perinatal em gestações que cursaram com amniorrexe prematura em maternidade pública do Norte do Brasil. Rev Bras Ginecol Obstet. 2014; 36(10):442-8.

2. Silva MAS, Collet N, Silva KL, Moura FM. The everyday of the family in coping with a chronic condition on infants. Acta Paul Enferm. 2010; 23(3):359-65.

3. McPherson M, Arango P, Fox H, Lauver C, McManus $M$, Newacheck PW, et al. A new definition of children with special health care needs. Pediatrics. 1998; 102(1):137-40. 
4. Dockerty SL, Barfield R, Thaxton C, Brandon D. Cuidado centrado na família de crianças com necessidades especiais. In: Honckenberry MJ. Wong Fundamentos de Enfermagem pediátrica. Rio de Janeiro: Elsevier; 2014. p. 515-44.

5. Rezende JMM, Cabral IE. As condições de vida das crianças com necessidades especiais de saúde: determinantes da vulnerabilidade social na rede de cuidados em saúde as crianças com necessidades especiais de saúde. Rev Pesq Cuid Fundam Online [periódico na Internet]. 2010 [citado 2015 set 7]; 2(Supl.):22-5. Disponível em: http://www. seer.unirio.br/index.php/cuidadofundamental/ article/view/773

6. Fereday J, Oster C, Darbyshire P. Partnership in practice: what parents of a disabled child want from a generic health professional in Australia. Health Soc Care Commun. 2010; 18(6):624-32.

7. Moraes JRMM, Cabral IE. The social network of children with special healthcare needs in the (in)visibility of nursing care. Rev Latino-Am Enfermagem. 2012; 20(2):282-8.

8. Wright LM, Leahey M. Enfermeiras e famílias: guia para avaliação e intervenção na família. 5ª ed. São Paulo: Roca; 2012.

9. Pedro ICS, Galvão CM, Rocha SMM, Nascimento LC. Social support and families of children with cancer: an integrative review. Rev Latino-Am Enfermagem. 2008; 16(3):477-83.

10. Pope $C$, Mays N. Pesquisa qualitativa na atenção à saúde. Porto Alegre: Artmed; 2009.

11. Bardin L. Análise de conteúdo. São Paulo: Edições $70 ; 2011$.
12. Vieira SS, Bevilacqua MC, Ferreira NMLA, Dupas G. Discovery of hearing impairment by the family: seeing an idealized future collapse. Acta Paul Enferm. 2012; 25(spe2):82-8.

13. Nóbrega VM, Collet N, Silva KL, Coutinho SED. Rede e apoio social das famílias de crianças em condição crônica. Rev Eletr Enf [periódico na Internet]. 2010 [citado 2015 set 7]; 12(3):43140. Disponível em: http://dx.doi.org/10.5216/ ree.v12i3.7566

14. Okido ACC, Pizzignacco TMP, Furtado MCC, Lima RAG. Technology-dependent children: the maternal care experience. Rev Esc Enferm USP. 2012; 46(5):1066-73.

15. Medeiros CS, Salomao NMR. Concepções maternas sobre o desenvolvimento da criança deficiente visual. Rev Bras Educ Espec. 2012; 18(2):283300.

16. Dantas MAS, Pontes JF, Assis WD, Collet N. Facilidades e dificuldades da família no cuidado à criança com paralisia cerebral. Rev Gaúcha Enferm. 2012; 33(3):73-80.

17. Neves ET, Silveira A. Challenges for family caregivers of children with special health care needs: contributions of nursing. Rev Enferm UFPE On line [Internet]. 2013 [cited 2015 sept 7]; 7(5):1458-62. Available from: http://www. revista.ufpe.br/revistaenfermagem/index.php/ revista/article/view/3229

18. Baltor MRR, Matos APK, Wernet M, Ferreira NMLA, Dupas G. The perceptions of families with children having chronic diseases and their relationships with healthcare professionals. Rev Esc Enferm USP. 2013; 47(4):808-14. 